(c) American Dairy Science Association, 2004.

\title{
Prediction of Longevity Breeding Values for US Holstein Sires Using Survival Analysis Methodology
}

\author{
D. Z. Caraviello, K. A. Weigel, and D. Gianola \\ Department of Dairy Science, \\ University of Wisconsin, Madison 53706
}

\begin{abstract}
Breeding values of Holstein sires for daughter longevity in each of 9 geographical regions of the United States were predicted using a Weibull proportional hazards model. Longevity (also commonly referred to as herd life or length of productive life) was defined as the number of days from first calving until culling or censoring. Records from 2,322,389 Holstein cows with first calving from 1990 to 2000 were used. In addition to the sire's additive genetic merit, our failure time model included time-dependent effects of herd-year-season of calving, parity-stage of lactation, and within-herd-year quintiles for mature equivalent fat plus protein yield, as well as the time-independent effect of age at first calving. Sire variances and parameters of the Weibull distribution were estimated separately for each region. The relative risk of culling for daughters of each individual sire was expressed relative to that of daughters of an average sire (within a specific region). Predicted breeding values for functional longevity, expressed as relative risk ratios, ranged from 0.7 to 1.3. Sizable differences were observed between geographical regions in sire rankings, as well as estimated sire variances and gamma parameters (of the distribution of herdyear-season effects), suggesting that a single national ranking may not be appropriate for every region. Two random samples of herds were selected from the full national data set; these contained 375,086 records and 256,751 records, respectively. Predicted transmitting abilities (PTA) of sires for daughter longevity were calculated using the Weibull proportional hazards (sire) model described previously but without the correction for milk production. These were compared with predictions from a linear (animal) model, as currently used for routine genetic evaluation of length of productive life in the United States. Logistic regression of daughters' stayability to $36,48,60,72$, or 84 mo of life (among
\end{abstract}

Received February 4, 2004.

Accepted June 21, 2004.

Corresponding author: K. A. Weigel; e-mail: weigel@calshp.cals. wisc.edu.

animals that had opportunity to stay that long) on sires' PTA indicated that the proportional hazards model yielded more accurate predictions of daughter longevity than the linear animal model, even though the latter relied on denser pedigree information.

(Key words: longevity, survival analysis, Holstein)

Abbreviation key: AIPL = Animal Improvement Programs Laboratory, $\mathbf{P L}=$ length of productive life, $\mathbf{R R}=$ relative risk of culling.

\section{INTRODUCTION}

New opportunities for genetic improvement of dairy cow longevity now exist due to the availability of inexpensive, powerful computer systems and efficient, public-domain software packages that can accommodate extremely large data sets. Survival analysis is used for routine genetic evaluation of dairy sires in several countries, mainly within Europe. It has replaced conventional linear model methodology due to theoretical advantages in the handling of censored records from animals that are still alive at the time of analysis, as well as possibilities for including time-dependent covariates in the model. Approximate estimates of the heritability of longevity traits using survival analysis typically range between 0.15 and 0.20 after transformation to the original scale, although estimates on the logarithmic scale are usually similar in magnitude (roughly 0.05 to 0.10 ) to estimates derived from linear models (VanRaden and Klaaskate, 1993; Ducrocq and Sölkner, 1998a). To the extent that higher heritability estimates translate into more rapid genetic progress, implementation of survival analysis methodology could have an important impact on dairy cattle improvement programs.

The current method for routine genetic evaluation of length of productive life (PL) in the United States was described by VanRaden and Klaaskate (1993). For completed records, the linear model analysis is based on total months in milk accumulated by 84 mo of age, with a maximum of 10 mo per lactation. For censored records, a regression-based projection of total months in milk is computed using data regarding current 
Table 1. States comprising each of the 9 US Standard Regions for Temperature and Precipitation.

\begin{tabular}{ll}
\hline North East & Maine, New Hampshire, Vermont, Massachusetts, Rhode Island, Connecticut, New York, New Jersey, \\
& Pennsylvania, Delaware, Maryland \\
South East & Virginia, North Carolina, South Carolina, Georgia, Florida, Alabama \\
Central & Michigan, Wisconsin, Iowa, Minnesota \\
East North Central & North Dakota, South Dakota, Nebraska, Montana, Wyoming \\
West North Central & Kansas, Mississippi, Arkansas, Louisiana, Oklahoma, Texas \\
South & Colorado, New Mexico, Arizona, Utah \\
South West & Idaho, Washington, Oregon \\
North West & Nevada, California \\
West &
\end{tabular}

months in milk, current months dry, current lactation status (milking or dry), and age at first calving.

Survival analysis is based on the concept of the hazard rate, which is the instantaneous probability of culling among animals that are still alive (Smith and Quaas, 1984; Ducrocq, 1987). The ability to include time-dependent covariates in survival analysis can make such models effective tools for analyzing dairy cow longevity data, because management and environmental conditions affecting a cow and her herdmates often change over time. Furthermore, censored records of cows that were sold for dairy purposes and cows that are still alive at the time of genetic evaluation often make up a large proportion of the data. Including such records is more straightforward using survival analysis rather than conventional linear models. Furthermore, longevity data usually have a skewed distribution and, in the absence of a suitable transformation, cannot be analyzed properly by methods that assume normality (Egger-Danner, 1993). Lastly, the relationship between longevity and explanatory variables is often nonlinear (Vukasinovic, 1999), and such relationships can be accommodated in survival models.

In large countries, such as Australia or the United States, environmental conditions and management practices may differ widely between geographical regions. Factors such as herd size, housing facilities, feeding programs, and heat stress can affect the voluntary and involuntary culling policies of individual herds. In this case, region-specific sire evaluations, or at least region-specific model parameters, may be needed.

The objectives of this study were 3 -fold. The first objective was to apply survival analysis methodology to the prediction of longevity breeding values for US Holstein sires. The second objective was to evaluate potential genotype $\times$ environment interactions between different geographical regions of the United States. The third objective was to compare (via cross-validation) the predictive ability of survival analysis with that of the linear model system used currently for routine genetic evaluation of PL in the United States.

\section{MATERIALS AND METHODS}

\section{Data}

Longevity data and production records were provided by the USDA Animal Improvement Programs Laboratory (AIPL). After editing, records from 2,322,389 US Holstein cows with first calving from January 1990 through November 2000 remained for analysis. All cows were required to have valid sire identification, as well as age at first calving between 18 and 42 mo. Herds were assigned to 9 geographical regions, based on the US Standard Regions for Temperature and Precipitation from the National Climatic Data Center (http:// www.ncdc.noaa.gov). The states comprising each region are listed in Table 1.

Longevity was defined as the number of days from first calving until culling or censoring. Records from cows that were sold for dairy purposes were considered censored on the date of sale, and records from cows in herds that discontinued milk recording were considered censored on the last reported test date. Observations from cows that completed 5 lactations were treated as censored at $305 \mathrm{~d}$ postpartum in the fifth lactation, and records from cows in first through fifth lactation that were still alive were considered censored as of the date of analysis. A substantial number of cows completed normal 305-d lactations but failed to return for the subsequent lactation; these cows were considered as dead (and uncensored) if they did not calve again within 6 mo after completion of their last reported lactation. Overall, $37.4 \%$ of the longevity records were censored.

Because voluntary culling for low production is an important reason for disposal, we also considered functional longevity or the ability to delay involuntary culling. Functional longevity was approximated by correcting true longevity for production, and this was accomplished by including the effect of within-herd-year quintile ranking for $305 \mathrm{~d}$ mature equivalent fat plus protein in the statistical models.

\section{Survival Analysis}

Our statistical model for the analysis of functional longevity in each geographical region was as follows: 


$$
\begin{gathered}
h_{i j k l m}(t)= \\
h_{0}(t) \exp \left[P_{i}\left(t_{1}\right)+\beta A_{j}+M_{k}\left(t_{1}\right)+h y_{l}\left(t_{2}\right)+s_{m}\right],
\end{gathered}
$$

where $h_{i j k l m}(t)=$ hazard function (instantaneous probability of culling) for a given cow at time $t ; t=$ time (measured in days) from first calving until death, culling, or censoring; $h_{0}(t)=$ Weibull baseline hazard function with scale parameter $\tau$ and shape parameter $\rho$; $P_{i}\left(t_{1}\right)=$ time-dependent fixed parity-stage of lactation effect, assumed to be piecewise constant with change points at $t_{1}=0,45$, or 270 in each lactation; $t_{1}=$ time (measured in days) from the beginning to the end of each lactation; $A_{j}=$ time-independent effect of age at first calving, treated as a continuous covariate with regression coefficient $\beta ; M_{k}\left(t_{1}\right)=$ time-dependent effect of within-herd-year quintile ranking for mature equivalent 305-d fat plus protein yield, assumed to be piecewise constant with change point at $t_{1}=0$ in each lactation; $h y_{l}\left(t_{2}\right)=$ time-dependent random effect of herd-year-season, assumed to be independently distributed, following a log-gamma distribution with parameter $\gamma$, and assumed to be piecewise constant with change points at $t_{2}=1$ (i.e., January 1), 121 (i.e., May 1), or 243 (i.e., September 1 ) in each calendar year; $t_{2}=$ time (measured in days) from the beginning to the end of each calendar year; $s_{m}=$ time-independent random effect of sire of cow, assumed to be distributed as multivariate normal with mean vector $\underset{\sim}{0}$ and covariance matrix $\underset{\sim}{A} \sigma_{s}^{2}$, where $\underset{\sim}{A}$ is the additive relationship matrix between sires.

The Survival Kit Version 3.12, a set of FORTRAN programs written by Ducrocq and Sölkner (1998b), was used for the Weibull analysis. Details were given in Ducrocq (1994), and theoretical aspects were discussed by Ducrocq and Casella (1996). This procedure employs an empirical Bayes approach to estimate fixed effects and sire variance components and to predict random sire effects. The pedigree file included only information regarding male parents, and the sire variance $\left(\sigma_{s}^{2}\right)$ was estimated as the mode of its marginal posterior density, as approximated by Laplacian integration. A sire model was chosen due to computational limitations, but the Survival Kit Version 3.12 can accommodate an animal model as well. To avoid computational difficulties due to herd-year-season classes with few animals (potentially with no uncensored failures), estimation of the parameters $\gamma, \sigma_{s}^{2}$, and $\rho$ was carried out using a random sample of herds with $\geq 100$ animals in each region; each sample contained approximately 30,000 animals. After estimating parameters as described previously, model (1) was applied to the full data set from each region. Breeding values for Holstein sires were predicted conditionally on corresponding values of $\gamma, \sigma_{s}^{2}$, and $\rho$.
Spearman correlation coefficients were used to assess the similarity (or lack thereof) between sire rankings in different geographical regions. In addition, for sires with at least 10 uncensored daughters in all 9 geographical regions, the percentages of the top 100 and top 1000 sires (based on relative risk of culling, $\mathbf{R R}$ ) that were in common between each pair of regions were determined. Three example sires with high, medium, or low RR in the East North Central region were also chosen, and their $R R$ values in all other regions were reported. Last, expected survival curves were created for 3 example sires with low, medium, or high RR in the Central region, and the number and percentage of sires with $R R$ $\leq 0.8$ (indicating outstanding daughter longevity) were reported for each region.

\section{Comparison with a Linear Model}

For comparison of the predictive ability of survival analysis and linear models, 2 random samples of herds were taken from the full national data set. The first sample contained 375,086 records from 4677 herds, whereas the second sample contained 256,751 records from 3202 herds. Because the linear model currently used for routine genetic evaluation of PL in the United States does not contain an adjustment for milk production, we estimated sire breeding values in each sample of herds using the survival analysis model (1) but without the time-dependent effect of within herd-year ranking for fat plus protein yield. The RR of culling for each sire was calculated conditionally on parameter estimates of 6.86 for $\gamma, 0.02$ for $\sigma_{s}^{2}$, and 0.7 for $\rho$. Next, we estimated sire PTA for PL in each of the 2 aforementioned samples of herds using the following linear model:

$$
y_{i j k l}=H Y S_{i}+A C_{j}+a_{k}+e_{i j k l},
$$

where $y_{i j k l}=$ completed or projected months in milk by 84 mo of age for a given cow; $H Y S_{i}=$ fixed effect of herdyear-season of first calving; $A C_{j}=$ fixed effect of age at first calving; $a_{k}=$ random additive genetic effect of animal $k$, assumed to be distributed as multivariate normal with mean vector $\underset{\sim}{0}$ and covariance matrix $\underset{\sim}{A}$ $\sigma_{a}^{2}$, where $\underset{\sim}{A}$ is now the relationship matrix between animals, and $\sigma_{a}^{2}$ is the additive genetic variance.

Model (2) is similar to the linear model used by the USDA-AIPL, except that projected observations for censored animals were regression-based predictions using age at first calving and current months in milk only (information regarding current months dry and current milking status was lacking). Genetic and residual variance components were estimated from the data using 
Table 2. Summary of data from each geographical region, including the percentage of (right) censored records, number of cows, number of herds, and average failure and censoring times, measured in days after first calving.

\begin{tabular}{llllll}
\hline Region & $\begin{array}{l}\text { No. } \\
\text { cows }\end{array}$ & $\begin{array}{l}\text { No. } \\
\text { herds }\end{array}$ & $\begin{array}{l}\text { Failure } \\
\text { time (d) }\end{array}$ & $\begin{array}{l}\text { Percent } \\
\text { censoring }\end{array}$ & $\begin{array}{l}\text { Censoring } \\
\text { time (d) }\end{array}$ \\
\hline North East & 382,444 & 2684 & 722 & $38.5 \%$ & 784 \\
South East & 144,786 & 717 & 684 & $34.3 \%$ & 760 \\
Central & 289,807 & 2152 & 679 & $36.3 \%$ & 762 \\
East North Central & 379,470 & 2874 & 657 & $36.2 \%$ & 750 \\
West North Central & 101,593 & 660 & 649 & $35.0 \%$ & 754 \\
South & 217,234 & 1210 & 666 & $37.3 \%$ & 742 \\
South West & 177,832 & 391 & 693 & $38.9 \%$ & 783 \\
North West & 280,283 & 798 & 696 & $37.2 \%$ & 755 \\
West & 348,940 & 445 & 700 & $39.7 \%$ & 722 \\
\hline
\end{tabular}

REML, and sire PTA were predicted by BLUP, conditionally on the estimated variance components.

Sire breeding values from application of the survival analysis model (1) for the 2 random subsets of data (A and $\mathrm{B}$ ) are denoted as $R R_{\mathrm{A}}$ and $R R_{\mathrm{B}}$, respectively. Likewise, sire PTA for PL from the linear model (2) in subsets $\mathrm{A}$ and $\mathrm{B}$ are denoted as $\mathrm{PL}_{\mathrm{A}}$ and $\mathrm{PL}_{\mathrm{B}}$, respectively. Stayability observations (i.e., binary indicators of survival to $36,48,60,72$, or 84 mo of age among daughters that had the opportunity to survive that long) for cows in data set A were regressed (using logistic regression) on $R R_{A}$ or $\mathrm{PL}_{\mathrm{A}}$, such that each sire's breeding value could be converted into his daughters' probability of survival to $36,48,60,72$, or 84 mo. Next, the expected number of daughters of each sire that would survive to $36,48,60,72$, or 84 mo of age (among those that had an opportunity to survive that long) in data set $\mathrm{B}$ was calculated by multiplying the probability of survival to a given age from data set A by the total number of daughters in data set $B$. The actual number of daughters in data set B that survived to $36,48,60$, 72 , or 84 mo of life, among those that had an opportunity to stay that long, was subsequently determined for each sire, and the observed and expected numbers of "survivors" and "failures" were compared using the following $\chi^{2}$ statistic:

$$
\begin{aligned}
\chi^{2} & =\left[(\text { Observed Survivors }- \text { Expected Survivors })^{2}\right. \\
& \left.+(\text { Observed Failures }- \text { Expected Failures })^{2}\right]
\end{aligned}
$$

These $\chi^{2}$ statistics were summed across sires (hence, weighted by the number of daughters of each sire), and the model that produced the smallest sum was regarded as the more accurate predictor of stayability. The reciprocal analysis was subsequently carried out, using survival probabilities computed from data set $\mathrm{B}$ to predict daughters' survival rates in data set A. Last, for sires with at least 50 uncensored daughters in both random samples, we computed Pearson product-moment corre- lations between the $R R_{A}, R R_{B}, P L_{A}, P L_{B}$, and November 2003 national sire PTA for PL, as calculated by the USDA-AIPL.

\section{RESULTS AND DISCUSSION}

As shown in Table 2, the percentage of censored records ranged from 34 to $40 \%$ between geographical regions. The highest average censoring $(784 \mathrm{~d})$ and failure (722 d) times were observed in the North East, whereas the lowest average failure time $(649 \mathrm{~d})$ was observed in the West North Central region, and the lowest average censoring time (722 d) was observed in the West. It is likely that variation in censoring rate and time is due to regional differences in herd size, climate (e.g., heat stress), housing, nutrition, and management. The number of cows used in the analysis ranged from 101,593 in the West North Central region to 382,444 in the North East, and the number of herds ranged from 445 in the West region to 2874 in the East North Central region. Mean herd size differed dramatically between regions, ranging from 132 in the East North Central region to 784 in the West region, and this may be one of the most important sources of variation among regions.

Estimates of the parameters $\gamma, \rho, \sigma_{s}^{2}$, and of heritability on a logarithmic scale are shown in Table 3. Herita-

Table 3. Estimates of the sire variance, $\gamma$ (parameter of the loggamma distribution of herd-year-season effects), $\rho$ (parameter of the Weibull distribution), and heritability on the log scale for each of the 9 geographical regions.

\begin{tabular}{llrll}
\hline & Sire & & & \\
Region & variance & \multicolumn{1}{l}{$\gamma$} & $\rho$ & $h_{\text {log }}^{2}$ \\
\hline North East & 0.03 & 10.3 & 0.74 & 0.06 \\
South East & 0.04 & 9.3 & 0.58 & 0.09 \\
Central & 0.05 & 9.0 & 0.77 & 0.11 \\
East North Central & 0.03 & 5.7 & 0.79 & 0.06 \\
West North Central & 0.06 & 7.9 & 0.78 & 0.13 \\
South & 0.03 & 3.5 & 0.64 & 0.06 \\
South West & 0.03 & 13.2 & 0.78 & 0.06 \\
North West & 0.04 & 13.9 & 0.70 & 0.08 \\
West & 0.02 & 9.8 & 0.74 & 0.05 \\
\hline
\end{tabular}




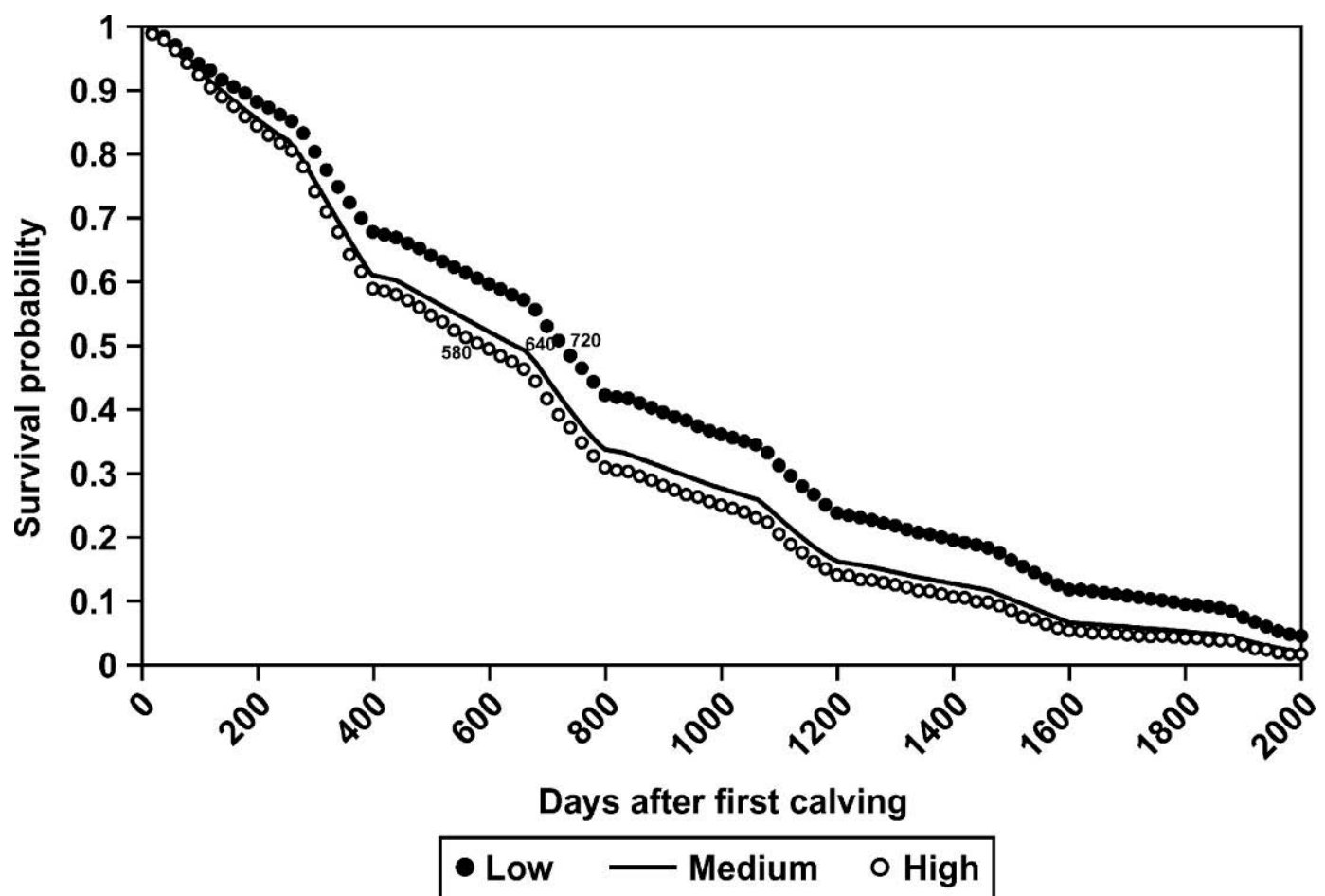

Figure 1. Example survival curves for Holstein sires with low (0.7), medium (1.0), and high relative risk (1.4) of culling in the Central region, with corresponding median survival times.

bility was approximated as in Ducrocq and Casella (1996):

$$
h_{\log }^{2}=\frac{4 \sigma_{s}^{2}}{\sigma_{s}^{2}+\Psi^{(1)}(\gamma)+\frac{\pi^{2}}{6}},
$$

where $\Psi^{(1)}(\gamma)$ is the trigamma function evaluated at $\gamma$, and $\frac{\pi^{2}}{6}$ is the variance of an extreme value distribution. Estimates of the $\gamma$ parameter ranged from 3.5 in the South to 13.9 in the North West, as shown in Table 3.
Estimates of $\rho$ ranged from 0.58 in the South East to 0.79 in the East North Central region, and estimates of the sire variances ranged from 0.02 in the West to 0.06 in the West North Central region. Estimates of $\rho$ were always less than 1 , which indicates that the failure rate decreased as time increased.

Heritability estimates on the log scale ranged from 0.05 in the West to 0.13 in the West North Central region. These results may reflect differences in the magnitude of genetic variation in cow longevity between regions, although they could result from differences in the accuracy of sire identification or record keeping between regions.

Table 4. Spearman rank correlations between predicted relative risk of culling for 320 Holstein sires with $\geq 25$ uncensored daughters in every geographical region.

\begin{tabular}{|c|c|c|c|c|c|c|c|c|c|}
\hline Region & $\begin{array}{l}\text { North } \\
\text { East }\end{array}$ & $\begin{array}{l}\text { South } \\
\text { East }\end{array}$ & Central & $\begin{array}{l}\text { East } \\
\text { North } \\
\text { Central }\end{array}$ & $\begin{array}{l}\text { West } \\
\text { North } \\
\text { Central }\end{array}$ & South & $\begin{array}{l}\text { South } \\
\text { West }\end{array}$ & $\begin{array}{l}\text { North } \\
\text { West }\end{array}$ & West \\
\hline \multicolumn{10}{|l|}{ North East } \\
\hline South East & 0.62 & & & & & & & & \\
\hline Central & 0.73 & 0.69 & & & & & & & \\
\hline East North Central & 0.71 & 0.62 & 0.74 & & & & & & \\
\hline West North Central & 0.60 & 0.55 & 0.65 & 0.61 & & & & & \\
\hline South & 0.63 & 0.59 & 0.68 & 0.65 & 0.57 & & & & \\
\hline South West & 0.56 & 0.48 & 0.58 & 0.55 & 0.53 & 0.59 & & & \\
\hline North West & 0.68 & 0.62 & 0.68 & 0.69 & 0.62 & 0.65 & 0.66 & & \\
\hline West & 0.64 & 0.57 & 0.59 & 0.62 & 0.53 & 0.61 & 0.64 & 0.68 & \\
\hline
\end{tabular}


Table 5. Percentage of selected sires in common between each pair of geographical regions for the top 100 sires (above diagonal) or top 1000 sires (below diagonal), based on relative risk of culling, for sires with $\geq 10$ uncensored daughters every region.

\begin{tabular}{llllllllll}
\hline & \multicolumn{1}{c}{$\begin{array}{l}\text { North } \\
\text { Region }\end{array}$} & $\begin{array}{l}\text { South } \\
\text { East }\end{array}$ & Central & $\begin{array}{l}\text { East } \\
\text { North } \\
\text { Central }\end{array}$ & $\begin{array}{l}\text { West } \\
\text { North } \\
\text { Central }\end{array}$ & South & $\begin{array}{l}\text { South } \\
\text { West }\end{array}$ & $\begin{array}{l}\text { North } \\
\text { West }\end{array}$ & West \\
\hline North East & & 22 & 24 & 26 & 18 & 17 & 19 & 23 & 16 \\
South East & 33 & & 29 & 24 & 38 & 28 & 22 & 32 & 23 \\
Central & 37 & 59 & & 33 & 33 & 21 & 23 & 27 & 23 \\
East North Central & 34 & 46 & 53 & & 26 & 19 & 21 & 29 & 21 \\
West North Central & 29 & 60 & 52 & 44 & & 27 & 29 & 31 & 28 \\
South & 34 & 57 & 57 & 45 & 51 & & 23 & 25 & 19 \\
South West & 32 & 53 & 51 & 43 & 53 & 52 & & 30 & 24 \\
North West & 33 & 55 & 52 & 49 & 51 & 53 & 55 & & 27 \\
West & 23 & 30 & 33 & 30 & 30 & 33 & 34 & 35 & \\
\hline
\end{tabular}

Survival analysis allows the expression of sires' genetic merit for daughter longevity in many different ways, such as RR, EBV in genetic standard deviation units, percentage of daughters expected to survive a given number of lactations, or expected PL. In the latter case, estimates correspond to specific points on the survival curve, $S(t)$, for a given bull's daughters. For example, median survival time occurs when $S(t)=0.50$. In this study, the genetic merit of a given sire for daughter longevity was expressed as RR, as compared with daughters of an average sire. For example, daughters of a sire with $R R=1.2$ are expected, on average, to have a 20\% higher risk of being culled than daughters of an average sire (with $R R=1.0$ ) at any given point in time.

Figure 1 shows example survival curves, $S(t)$, for Holstein sires with low (0.7), medium (1.0), or high RR (1.4) in the Central region. Longer survival times are represented by flatter (more gently sloping) survival curves. The 50th percentile (median) survival time can be used to compare the survival distributions of these sires. Median survival times were 720, 640, and $580 \mathrm{~d}$ after first calving for example sires with low, medium, and high RR, respectively.
Table 4 shows rank correlations for RR between regions for 320 Holstein sires that had $\geq 25$ uncensored daughters in every region. Correlations ranged from 0.48 to 0.74 , indicating that sires may rank differently for daughter longevity between regions. The lowest correlation occurred between the South West and South East regions, and the highest correlation was observed between the East North Central and Central regions. However, it is important to note that the expected values of these correlations are less than unity, because evaluations for some sires are based on relatively few progeny (hence, these sires have low reliability) in certain regions.

Table 5 illustrates the potential impact of regionspecific sire evaluations on selection decisions by showing the percentage of sires that were in common between each pair of regions when the top 100 (above diagonal) or the top 1000 (below diagonal) sires were chosen, based on RR. Among the top 100 sires, the percentage of common bulls ranged from 16 to $38 \%$, whereas among the top 1000 sires, this percentage ranged from 23 to $60 \%$. The West region differed most noticeably, probably because of large differences in herd size and management practices as compared with the

Table 6. Relative risk of culling for the top 3, middle 3, and bottom 3 sires from the East North Central region, compared with their estimated relative risks of culling in each of the other geographical regions (the number of progeny of each sire in each region is shown in parentheses).

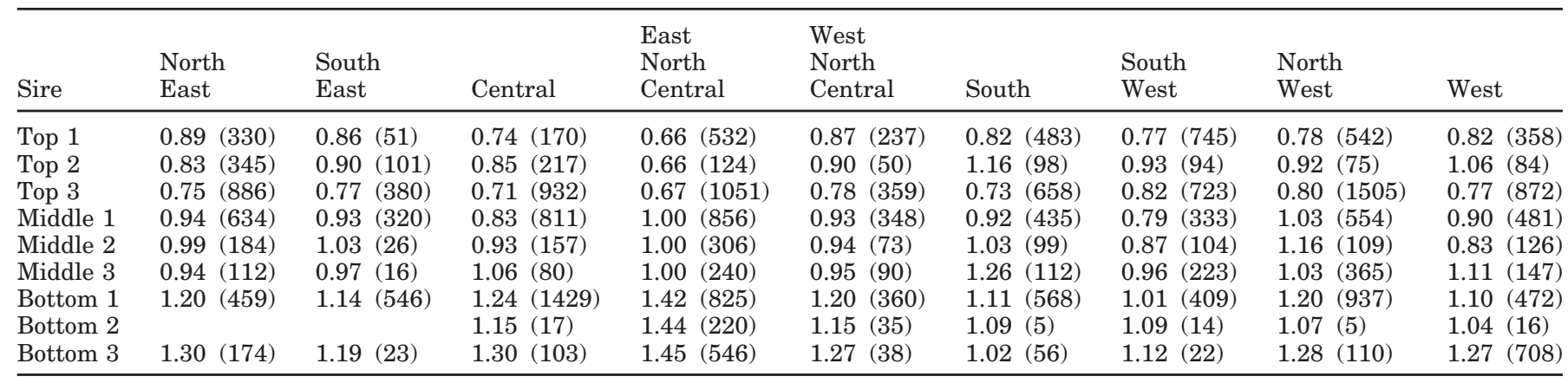


Table 7. Total number of sires, mean number of progeny per sire, number of sires with relative risk of culling $<0.8$, and percentage of sires with relative risk of culling $<0.8$ in each geographical region.

\begin{tabular}{lllll}
\hline & $\begin{array}{l}\text { Total no. } \\
\text { Rires }\end{array}$ & $\begin{array}{l}\text { No. progeny } \\
\text { per sire }\end{array}$ & $\begin{array}{l}\text { No. sires } \\
\text { with risk } \\
<0.8\end{array}$ & $\begin{array}{l}\text { Percentage } \\
\text { of sires with } \\
\text { risk }<0.8\end{array}$ \\
\hline North East & 12,932 & 30 & 41 & 0.32 \\
South East & 8017 & 18 & 14 & 0.17 \\
Central & 11,091 & 26 & 30 & 0.27 \\
East North Central & 13,573 & 28 & 64 & 0.47 \\
West North Central & 7001 & 15 & 26 & 0.37 \\
South & 10,724 & 20 & 33 & 0.31 \\
South West & 10,134 & 18 & 21 & 0.21 \\
North West & 11,118 & 25 & 28 & 0.25 \\
West & 15,273 & 23 & 43 & 0.28 \\
\hline
\end{tabular}

other regions. Once again, it is important to note that the percentage of selected bulls that are in common between a given pair of regions can be influenced by the reliability of evaluations for these sires. Table 6 shows the RR for the top 3, middle 3, and bottom 3 sires in the East North Central region, as well as their $R R$ in each of the other 8 regions and their progeny group size in each region. Although there is general agreement in the relative merit of these sires between regions, these differences could impact the usage of certain sires.

The majority of sires had $R R$ values between 0.9 and 1.1 in all regions, but some regions had a higher percentage of extreme sires (with $R R \leq 0.8$ ), as shown in Table 7. These differences may reflect a greater amount of genetic variation in certain regions, as a function of variation in sires' reaction norms to different management and climate conditions. However, it is important to note that the percentage of sires with extremely high or low $R R$ values also depends on average progeny group size in each region.

Table 8 shows Pearson product-moment correlations between EBV from the survival analysis and the linear models for sires with at least 50 uncensored daughters in each random subset of the national data set. Correlations of each estimate with the November 2003 USDAAIPL sire evaluations for PL are also shown. Correlations between national PL evaluations and the linear model estimates from our study were 0.72 and 0.71 in subsets A and B, respectively, whereas corresponding correlations with the survival analysis estimates from our study were -0.75 and -0.72 , respectively. Correlations between linear model and survival analysis estimates within each subset of the data ranged from -0.71 to -0.73 , but correlations between subsets were higher for survival analysis (0.70) than for the linear model (0.61).

Table 9 shows results of the $\chi^{2}$ comparison of predicted and observed stayability to $36,48,60,72$, or 84 mo of age in the cross-validation analysis. As shown in the table, survival analysis generally provided more accurate predictions of daughter longevity than the corresponding linear model. Predictions from data set A were more closely related to actual stayability (in data set B) to 48,60 , or 72 mo of age. Likewise, predictions from data set $B$ were better predictors of daughter stayability to 48,60 , or 72 mo of age in data set A. These cross-validation results tend to agree with previous results obtained in US Jerseys by Caraviello et al. (2004).

\section{CONCLUSIONS}

Implementation of survival analysis methodology for routine evaluation of daughter longevity could be justified based on theoretical considerations alone, as this approach offers an opportunity to include time-dependent explanatory variables, provides a more appropriate treatment of censored observations, and does not require the assumption of normally distributed failure times. Furthermore, results from our study suggest that survival models can enhance the accuracy of predicted breeding values for daughter longevity in practice. Independent predictions (from random subsets of data) of daughter stayability to various ages were more closely related to actual culling rates when using survival analysis than corresponding linear models, despite the fact that the linear (animal) model used more pedigree information than the survival (sire) model.

Table 8. Pearson correlation coefficients between relative risk of culling from the survival analysis $\left(R R_{A}\right.$ and $\left.R R_{B}\right)$, predictions of productive life $\left(\mathrm{PL}_{\mathrm{A}}\right.$ and $\left.\mathrm{PL}_{\mathrm{B}}\right)$ from the linear model, and the USDA Animal Improvement Programs Laboratory national genetic evaluations for productive life ( $\left(\mathrm{L}_{\text {National }}\right)$ for sires with $\geq 50$ uncensored daughters in random subsets $\mathrm{A}$ and $\mathrm{B}$.

\begin{tabular}{lcrrrr}
\hline & $\mathrm{PL}_{\text {National }}$ & $\mathrm{PL}_{\mathrm{A}}$ & $\mathrm{PL}_{\mathrm{B}}$ & $\mathrm{RR}_{\mathrm{A}}$ & $\mathrm{RR}_{\mathrm{B}}$ \\
\hline $\mathrm{PL}_{\text {National }}$ & & & & & \\
$\mathrm{PL}_{\mathrm{A}}$ & 0.72 & & & & \\
$\mathrm{PL}_{\mathrm{B}}$ & 0.71 & 0.61 & & & \\
$\mathrm{RR}_{\mathrm{A}}$ & -0.75 & -0.73 & -0.52 & & \\
$\mathrm{RR}_{\mathrm{B}}$ & -0.72 & -0.56 & -0.71 & 0.70 & \\
\hline
\end{tabular}


Table 9. Sum of $\chi^{2}$ statistics across sires, based on comparing the predicted vs. observed number of survivors to $36,48,60,72$, or 84 mo of age, among daughters that had an opportunity to survive that long, in each subset of the data (using probabilities of survival derived from the other subset), with smaller sums indicating more accurate predictions of daughter stayability.

\begin{tabular}{llrr}
\hline Prediction of survival & $\begin{array}{l}\text { Stayability } \\
\text { to age }(\mathrm{mo})\end{array}$ & $\begin{array}{l}\text { Linear } \\
\text { model }\end{array}$ & $\begin{array}{r}\text { Survival } \\
\text { analysis }\end{array}$ \\
\hline $\begin{array}{c}\text { In data set B from sire EBV } \\
\text { calculated in data set A }\end{array}$ & 36 & & \\
& 48 & 270,615 & 278,734 \\
& 60 & 244,037 & 192,325 \\
& 72 & 219,170 & 158,610 \\
& 84 & 87,956 & 75,069 \\
In data set A from sire EBV & & 21,549 & 18,698 \\
calculated in data set B & 36 & & \\
& 48 & 490,565 & 521,140 \\
& 60 & 517,205 & 419,929 \\
& 72 & 407,713 & 313,916 \\
& 84 & 175,223 & 160,050 \\
& & 44,792 & 45,983 \\
\hline
\end{tabular}

Heritability estimates, as well as estimates of the parameters of the Weibull distribution and the log-gamma distribution of herd-year-season effects, differed between geographical regions. Presumably these differences, as well as differences in mean survival time and percentage of censoring, are due to regional variation in herd size, heat stress, housing facilities, and other management practices. Sire rankings also differed between regions, but the practical inconvenience of calculating separate genetic evaluations for different regions may negate potential benefits from more precise modeling. Although survival analysis methodology is computationally demanding, especially with an animal model, this should not preclude its implementation on a national scale. Furthermore, no additional data collection costs would be incurred if survival analysis methodology were to replace the linear model approach currently used for routine genetic evaluation of PL in US Holstein cattle.

\section{ACKNOWLEDGMENTS}

Financial support of the National Association of Animal Breeders (Columbia, MO), the Holstein Association USA (Brattleboro, VI), and the Babcock Institute for International Dairy Development (Madison, WI) is gratefully acknowledged. Data were generously provided by the USDA-ARS Animal Improvement Programs Laboratory (Beltsville, MD). Software and technical assistance were provided by Vincent Ducrocq.

\section{REFERENCES}

Caraviello, D. Z., K. A. Weigel, and D. Gianola. 2004. Comparison between a Weibull proportional hazards model and a linear model for predicting the genetic merit of US Jersey sires for daughter longevity. J. Dairy Sci. 87:1469-1476.

Ducrocq, V. 1987. An analysis of length of productive life in dairy cattle. Ph.D. Diss., Cornell Univ., Ithaca, NY.

Ducrocq, V. 1994. Statistical analysis of length of productive life for dairy cows of the Normande breed. J. Dairy Sci. 77:855-866.

Ducrocq, V., and G. Casella. 1996. A Bayesian analysis of mixed survival models. Genet. Sel. Evol. 28:505-529.

Ducrocq, V., and J. Sölkner. 1998a. Implementation of a routine breeding value evaluation for longevity of dairy cows using survival analysis techniques. Proc. 6th World Cong. Genet. Appl. Livest. Prod., Armidale, Australia 27:447-448.

Ducrocq, V., and J. Sölkner. 1998b. The Survival Kit-V3.0: A package for large analyses of survival data. Proc. 6th World Cong. Genet. Appl. Livest. Prod., Armidale, Australia 22:51-52.

Egger-Danner, C. 1993. Zuchtwertschätzung für merkmale der langlebigkeit beim rind mit methoden der lebensdaueranalyse. Ph.D. Diss., Univ. für Bodenkultur, Vienna, Austria.

Smith, S. P., and R. L. Quaas. 1984. Productive lifespan of bull progeny groups: Failure time analysis. J. Dairy Sci. 67:2999-3007.

VanRaden, P. M., and E. J. H. Klaaskate. 1993. Genetic evaluation of length of productive life including predicted longevity of live cows. J. Dairy Sci. 76:2758-2764.

Vukasinovic, N. 1999. Application of survival analysis in breeding for longevity. Interbull Bull. 21:3-10. 